\title{
Synergistic Effect of Zinc Oxide Nanoparticles and Vancomycin on Methicillin resistant Staphylococcus aureus
}

\author{
Reyam Thamer Ghazi ${ }^{*}$ Essra Ghanim Alsammak \\ Department of Biology, College of Science, University of Mosul, Mosul, Iraq (reyamthamer1991@gmail.com ; \\ esrsbio19@uomosul.edu.iq) \\ *Correspondence: reyamthamer1991@gmail.com
}

\begin{abstract}
The study was carried out on (120) various clinical samples collected from patients attended Al Salam and Al-Khansa Hospitals and the Public Health Laboratory in the Mosul city during 4 months (September - December 2019). Samples were cultured on Mannitol Salt Agar medium, 105 samples give a positive result (grew the bacteria). 50 isolates were fermented mannitol sugar, at a rate of $47.6 \%$, depending on the phenotypic characteristics and production of Coagulase, 14 isolates were identified, at a rate of $13.3 \%$, belonging to Staphylococcus aureus the diagnosis were confirmed using VITEK system. The highest isolation rate from wounds was $57 \%$, then abscesses $21 \%$, blood samples $14 \%$, and urinary tract infections $7 \%$. The sensitivity of the isolates was tested for 16 antibiotics, the isolates showed variation in their resistance to antibiotics. Most of the isolates showed high resistance at $92.8 \%$ to each of Oxacillin, Vancomycin, which were diagnosed as MRSA and VRSA. Vancomycin MICs against MRSA and VRSA ranged (2500-5000) $\mu \mathrm{g} / \mathrm{mL}$. MIC for nanoparticles sized $(30,20,50-150) \mathrm{nm}$ ranged $(5000-10000) \mu \mathrm{g} / \mathrm{mL}$ for isolates that are positive coagulase. In this study the efficacy of vancomycin was improved in combination with $\mathrm{ZnO}$ nanoparticles. Results showed a decrease in vancomycin MICs from (2500-5000) $\mu \mathrm{g} / \mathrm{mL}$ to $(39$ 78.125) $\mu \mathrm{g} \backslash \mathrm{mL}$ when mixed with $\mathrm{ZnO} 20 \mathrm{~nm}$.
\end{abstract}

Keywords: Coagulase, Nanoparticles, VITEK system, MRSA, VRSA.

Received: October $10^{\text {th }}, 2020 /$ Accepted: December 04 $4^{\text {th }}, 2020 /$ Online: December $28^{\text {th }}, 2020$

\section{INTRODUCTION}

Staphylococcus aureus is a bacterium that lives on the skin, nose and mucous membranes of the human respiratory system, whether it is naturally occurring bacteria or invading bacteria, they cause many infections such as bacteremia, pneumonia, skin and soft tissue infections such as abscesses, boils, postoperative wound infections and toxic shock syndrome. (TSS) Toxic Shock Syndrome and Scalded Skin Syndrome (SSS) (Asanin et al., 2019; Reddy et al., 2017; Goudarzi et al., 2016).

Staphylococcus is found naturally in about $30 \%$ of healthy people, yet it is one of the most common pathogenic bacteria in community and hospital (Tong et al., 2015). Infections associated with pyogenic staphylococcus are often complicated by their ability to resist different classes of antibiotics and thus become more pathogenic (Rao et al., 2014).

The most important strains with multiple antibiotic resistance are Methicillin Resistant Staphylococcus aureus, which has become a major concern for hospital injuries, so vancomycin was chosen as the last line for the treatment of MRSA infections

doi: 10.38094/jlbsr1332
(Reddy et al., 2017). This led to the emergence of strains resistant to vancomycin (VRSA), Vancomycin Resistant Staphylococcus aureus, which was first diagnosed in the United States (Tortora et al., 2018), in addition to the emergence of strains resistant to Erythromycin (ERSA) Resistant Staphylococcus aureus Erythromycin, which was later diagnosed (Tille, 2017).

The increase in antibiotic resistance led to an increase in research to find alternative agents and treatments, including the use of nanoparticles, which showed a synergistic effect with antibiotics against bacteria as the rate of inhibition of bacterial growth is higher than the rate of inhibition when using antibiotics and nanoparticles both separately (Fayaz et al., 2010).

$\mathrm{ZnO}$ is one of the most famous metal oxides that have many properties, the most important of which are antimicrobiological activity and semiconductor properties, and it is safe and non-toxic (Maruthupandy et al., 2016). It is also used in many industries such as rubber, dyes, cosmetics, and sunscreens and food and pharmaceutical products as it acts as a

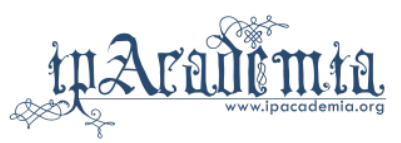


medicinal agent in many fields (Kołodziejczak-Radzimska and Jesionowski, 2014). The mechanism of action of $\mathrm{ZnO}$ is the penetration of the bacterial cell wall by diffusion, which was observed by SEM and TEM microscopy images of the bacterial cells as it breaks down the biofilm and collects in the cytoplasm and interacts with biomolecules causing programmed cell death (Siddiqi et al., 2018).

The metal oxide nanoparticles, first destroy the bacterial cell membrane and then penetrate into it. Hydrogen peroxide $\left(\mathrm{H}_{2} \mathrm{O}_{2}\right)$ is formed from zinc oxide, which acts as an antimicrobial (Yamamoto et al., 2004). Pati et al. (2014) showed that the nanoparticles of Zno, after rupturing the bacterial cell membrane, reduce the hydrophobic surface of the cell and work to reduce the reproduction of the oxidative stress genes in bacteria as well as enhance bacterial killing inside cells by stimulating or stimulating the production of (ROS). Reactive Oxygen Species and inhibit hemolysis induced by pathogenproduced hemolysin toxins (Cho et al., 2011).

Zinc oxide nanoparticles have selective bacterial toxicity, show fewer side effects on human cells, and are recommended for use in the food and agricultural industries (Ahmadi Shadmehri et al., 2019; Zhang et al., 2007). Nanoparticles prevent the formation of biofilms (Hajipour et al., 2012), $\mathrm{ZnO}$ inhibits the adhesion of bacteria to each other, and the smaller the size and the higher the surface area to mass ratio, the greater the prevention of biofilm formation (Slomberg et al., 2013). The formation of biofilms is an important mechanism, as the biofilms play an important role in the development of bacterial resistance. Scanning electron microscope (SEM) images and (TEM) Transmission Electron Microscopy has also been proven. The characteristics of $\mathrm{ZnO}$ nanoparticles depend on the size, shape, concentration, and exposure period of these particles (Wang et al., 2016).

The current study aimed to isolate and diagnosis of multiple antibiotic-resistant Staphylococcus aureus, especially MRSA and VRSA, from different clinical sources, and studying the genetic and phenotypic relationship between isolates. A study of the prevalence of resistance to treatments and nanoparticles among isolates .Determination of the minimum inhibitory concentration of antibiotics, zinc oxide in different sizes. To test the synergistic effect between antibiotics, nanoparticles.

\section{MATERIALS AND METHODS}

Clinical samples (120) were collected from patients at Al Salam and Al-Khansa Hospitals and the Public Health Laboratory in the city of Mosul for the period. From September 2019 to December 2019.

Samples were obtained from urinary tract infections (10 samples), wounds (65 samples), pus (20 samples), blood (25) and for both sexes. Clinical samples were cultured on Mannitol Salt Agar and morphological and biochemical characteristics, like the catalase, oxidase and clotting enzyme tests, sensitivity to Bacitracin, and VITEC system were used to identify staphylococcal species.

Sensitivity testing was performed using Kirby-Bauer disc diffusion method (Kirby-Bauer et al.1966) according to
Clinical Laboratory Standard Institute (CLSI, 2019) recommendations.

\section{A. Measurement Vancomycin Minimum Inhibitory Concentration}

The double dilution method was used, based on the method of Saginur et al., 2006 as follows: Add $1000 \mu \mathrm{l}$ of nutrient broth to 10 test tubes. $1000 \mu \mathrm{l}$ of pre-prepared antibiotic at a concentration of $10,000 \mu \mathrm{g} / \mathrm{mL}$ was added to tube No. 1. The antibiotic was mixed by using a micropipette by withdrawing the culture 6-8 times to obtain a concentration of $5000 \mu \mathrm{g} / \mathrm{mL}$. Transfer $1000 \mu \mathrm{l}$ from Tube No. 1 to Tube No. 2 and mix in the same way as the previous method to obtain a concentration of $2500 \mu \mathrm{g} / \mathrm{mL}$. The process was repeated up to tube No. 10, of which $1000 \mu \mathrm{l}$ was withdrawn and discarded. Thus, the concentrations were obtained $(5000,2500,1250,625,312.5$, $156.25,78.125,39,19.5)$ micrograms $/ \mathrm{mL}$. Add 100 microliters of bacterial suspension incubated for (18-24) hours at a concentration of $1.5 * 108$ cells / $\mathrm{mL}$ compared to the third tube of McFarland tubes. Add to tube No. 11 the nutrient broth and bacterial suspension only as positive control. Tube No. 12 contains only the nutrient broth as negative control. The tubes were incubated at $37{ }^{\circ} \mathrm{C}$ for (18-24) hours. Examination of bacterial growth is visible and the MIC observed the lowest inhibitory concentration of the antibiotic.

\section{B. Minimum Inhibitory Concentration of Zinc Nanoparticles in sizes $(30,20,50-150) \mathrm{nm}$}

The same previous method was used using a concentration of 20000 micrograms/mL previously prepared (where the required concentration of nanoparticles was dissolved in deionized water and sterilized by autoclave) to tube No. 1 and thus we obtain the concentrations $(10,000,5000,2500,1250,625,312.5$, $156.25,78.125,39) \mu \mathrm{g} / \mathrm{mL}$ for nanomaterials (Saginur et al., 2006).

\section{Study the synergistic effect of antibiotics with nanoparticles}

The double dilution method was used, based on the method of Saginur et al., 2006 as follows :Add $1000 \mu \mathrm{l}$ of nutrient broth to 10 test tubes. $1000 \mu \mathrm{l}$ of the MIC concentration determined from the previous step for each antibiotic and nanoparticle was added to the first tube to study the synergistic effect of the nanoparticles with the antibiotics. The mixing was done through the use of a micropipette by withdrawing the culture for (6-8) times. Transfer $1000 \mu \mathrm{l}$ from tube No. 1 to tube No. 2 which also contains $1000 \mu \mathrm{l}$ of the nutrient broth and mixing in the same way as before. The process was repeated up to tube No. 10, of which $1000 \mu \mathrm{l}$ was withdrawn and discarded. Adding $100 \mu \mathrm{l}$ of 24-hour age, bacterial culture at a concentration of $1.5 * 10^{8}$ cells $/ \mathrm{mL}$ compared to the third tube of McFarland tubes. The tubes were incubated at (37) $\mathrm{C}^{\circ}$ for (18-24) hours. Examination of the bacterial growth is visible, and the MIC was observed to have the lowest inhibitory concentration of the antagonist and the synergistic particles. 


\section{RESULTS}

120 samples were collected, including wound swabs, blood, pus and urinary tract infections for isolating of pyogenic staphylococcus using Mannitol Salt Agar medium, 105 of which showed growth on MSA medium at $87.5 \%$ of which 50 were fermented mannitol sugar isolates at $47.7 \%$ and 55 nonfermented isolates at $52.3 \%$, as shown in Table 1 .

Table 1. Number and percentage of isolates on mannitol salt agar

\begin{tabular}{|c|c|c|c|c|}
\hline $\begin{array}{c}\text { Total } \\
\text { number of } \\
\text { samples }\end{array}$ & $\begin{array}{c}\text { Growth on an } \\
\text { MSA }\end{array}$ & $\begin{array}{c}\text { No } \\
\text { growth }\end{array}$ & $\begin{array}{c}\text { Fermented } \\
\text { mannitol } \\
\text { isolates }\end{array}$ & $\begin{array}{c}\text { Non-fermented } \\
\text { mannitol isolates }\end{array}$ \\
\hline \multirow{3}{*}{ Total } & 105 & 15 & 50 & 55 \\
\cline { 2 - 6 } & $\% 87.5$ & $\% 12.5$ & $\% 47.6$ & $\% 52.3$ \\
\cline { 2 - 6 } & \multicolumn{2}{|c|}{120} & \multicolumn{3}{c}{105} \\
\hline
\end{tabular}

The biochemical tests shown in Table 2 are used to diagnose $S$. aureus and conformity as reported in internationally approved diagnostic systems (Winn et al., 2006; Collee et al., 1996). Fourteen of the 50 fermented mannitol isolates gave a positive result for the clotting enzyme test, at a rate of $28 \%$.

Table 2. Biochemical tests used to diagnose S. aureus under the study

\begin{tabular}{|c|c|c|c|c|c|c|c|c|c|}
\hline $\begin{array}{l}\text { Oxi } \\
\text { dase }\end{array}$ & $\begin{array}{l}\text { Cata } \\
\text { lase }\end{array}$ & $\begin{array}{l}\text { Haemo } \\
\text { ltsin }\end{array}$ & $\begin{array}{c}\text { Mannit } \\
\text { ol salt } \\
\text { Agar }\end{array}$ & $\begin{array}{l}\text { Moti } \\
\text { lity } \\
\text { Test }\end{array}$ & $\begin{array}{l}\text { Glou } \\
\cos \end{array}$ & $\begin{array}{l}\text { Lacto } \\
\mathrm{s}\end{array}$ & $\begin{array}{c}\text { Bacitr } \\
\text { acin }\end{array}$ & $\begin{array}{l}\text { Coag } \\
\text { ulase }\end{array}$ & $\begin{array}{l}\mathrm{Gr} \\
\text { am } \\
\text { sta } \\
\text { in }\end{array}$ \\
\hline- & + & + & + & - & + & + & + & + & + \\
\hline \multicolumn{10}{|c|}{ Number and ratio } \\
\hline 50 & 50 & 1. & 50 & 50 & 50 & 50 & 50 & 14 & 50 \\
\hline 100 & 100 & $\% 26$ & 100 & 100 & 10 & 10 & 100 & $\% 28$ & 10 \\
\hline$\%$ & $\%$ & & $\%$ & $\%$ & $\% 0$ & $\% 0$ & $\%$ & & $\% 0$ \\
\hline
\end{tabular}

The highest isolation rate obtained was in post-operative wound swab samples, reaching $57.1 \%$, followed by pus samples at $21.4 \%$, then blood samples at $14.2 \%$, and urinary tract infection samples, at $7.1 \%$ (Table 3 ).

Table 3. The ratios of $S$. aureus, depending on the type of specimen

\begin{tabular}{|c|c|c|c|c|}
\hline No. & Sample type & $\begin{array}{c}\text { The number } \\
\text { of samples }\end{array}$ & $\begin{array}{c}\text { The number } \\
\text { of isolates }\end{array}$ & $\begin{array}{c}\text { Isolation } \\
\text { ratio }\end{array}$ \\
\hline 1 & Wounds & 65 & 8 & 57.1 \\
\hline 2 & Abscesses & 20 & 3 & 21.4 \\
\hline 3 & Blood & 25 & 2 & 14.2 \\
\hline 4 & $\begin{array}{c}\text { Urinary tract } \\
\text { infections }\end{array}$ & 10 & 1 & 7.1 \\
\hline Total & & 120 & 14 & 100 \\
\hline
\end{tabular}

\section{A. Antibiotic Sensitivity Test}

The $S$. aureus sensitivity test was performed to 16 antibiotics by using dick diffusion method on Muller-Hinton Agar according to CLSI to determine the sensitivity or resistance of bacterial isolates to antibiotics by measuring the inhibition zone comparing the results with (CLSI, 2019) as shown in Figure 1, $S$. aureus is highly resistant to many antibiotics such as Bacitracin and Cefoxitin with $100 \%$ resistance. Vancomycin and Oxacillin which is one of the methicillin group, as it resisted 13 isolates with a resistance rate of $92.8 \%$.

Figure 1 illustrates the sensitivity of $S$. aureus for methicillin MSSA, at a rate of $7.1 \%$.

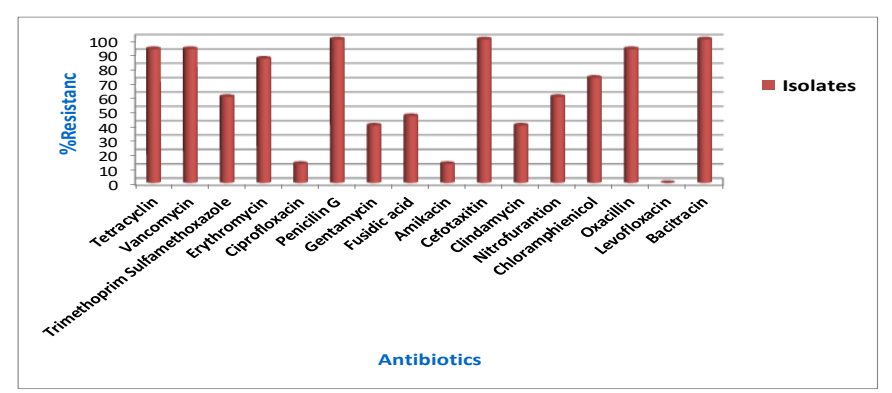

Figure 1. Percentages of resistance of S. aureus against a number of antibiotics.

\section{B. Measurement of the Minimum Inhibitory Concentration of Vancomycin}

The minimum inhibitory concentration MIC of vancomycin was determined, which gave the highest resistance against the bacterial isolates under study. Which ranged between (50002500) $\mu \mathrm{g} / \mathrm{mL}$ for the Vancomycin as in the Table 4.

Table 4. Minimum inhibitory concentration of vancomycin against S. aureus

\begin{tabular}{|c|c|c|c|c|c|c|c|}
\hline Isolates No. & S1 & S2 & S3 & S4 & S5 & S6 & S7 \\
\hline MIC $\mu \mathrm{g} / \mathrm{mL}$ & 5000 & 5000 & 5000 & 2500 & 5000 & 2500 & 5000 \\
\hline Isolates No. & S8 & S9 & S10 & S11 & S12 & S13 & S14 \\
\hline MIC $\mu \mathrm{g} / \mathrm{mL}$ & 2500 & 5000 & 2500 & 2500 & 5000 & 5000 & 5000 \\
\hline
\end{tabular}

\section{Measurement of the Minimum Inhibitory Concentration of Zinc Nanoparticles}

The minimum inhibitory concentration MIC of zinc oxide nanoparticles ( $\mathrm{ZnO}-\mathrm{NP})$ of 20, 30 and (50-150) nm, appeared between (10,000-5000) $\mu \mathrm{g} / \mathrm{mL}$ (Table 5).

Table 5. Minimum inhibitory concentration MIC of ZnO nanoparticles against $S$. aureus MRSA and VRSA under the study

\begin{tabular}{|c|c|c|c|c|c|c|c|c|c|c|c|c|c|c|}
\hline \multirow{2}{*}{$\begin{array}{l}\text { Isolates No. } \\
\text { Nanoparticles }\end{array}$} & \multicolumn{14}{|c|}{$\mathrm{MIC} \mu \mathrm{g} / \mathrm{mL}$} \\
\hline & S1 & $\mathrm{S} 2$ & S3 & $\mathrm{S} 4$ & S5 & S6 & S7 & $\mathrm{S} 8$ & S9 & S10 & $\mathrm{S} 11$ & S12 & S13 & S14 \\
\hline $\mathrm{ZnO} 20 \mathrm{~nm}$ & 5000 & 5000 & 10000 & 5000 & 10000 & 5000 & 10000 & 5000 & 10000 & 5000 & 10000 & 5000 & 10000 & 10000 \\
\hline $\mathrm{ZnO} 30 \mathrm{~nm}$ & 5000 & 10000 & 10000 & 5000 & 10000 & 10000 & 10000 & 5000 & 5000 & 5000 & 10000 & 10000 & 5000 & 10000 \\
\hline $\begin{array}{c}\mathrm{ZnO} \\
50-150 \mathrm{~nm}\end{array}$ & 5000 & 10000 & 5000 & 10000 & 5000 & 10000 & 10000 & 5000 & 10000 & 5000 & 10000 & 10000 & 5000 & 10000 \\
\hline
\end{tabular}




\section{Study of The Synergistic Effect of Zinc Nanoparticles with Vancomycin}

The effect of the relationship between the vancomycin used in the study and the zinc nanoparticles on the MRSA and vancomycin VRSA-resistant $S$. aureus when mixed together using the tube method. Where the results showed that the rate of MIC for each of the antibiotics and the nanoparticles and their different sizes decreased significantly. The results showed that the MIC values of Vancomycin when combined with zinc oxide of $20 \mathrm{~nm}$ and $30 \mathrm{~nm}$ sizes ranged from (39-78.125) $\mu \mathrm{g} / \mathrm{mL}$, and the MIC value ranged (39-156.25) $\mu \mathrm{g} / \mathrm{mL}$ when mixed with nanostructured zinc oxide at a volume of $50 \mathrm{~nm}$ while the MIC value of the antibiotic alone was between (25005000) $\mu \mathrm{g} / \mathrm{mL}$ (Table 6).

Table 6. Synergistic effect between vancomycin antagonist and zinc

\begin{tabular}{|c|c|c|c|c|c|c|c|}
\hline \multirow[t]{2}{*}{$\begin{array}{l}\text { Isola } \\
\text { tes } \\
\text { No. }\end{array}$} & \multirow{2}{*}{$\begin{array}{l}\text { MIC of } \\
\text { Vancom } \\
\text { ycin } \\
\text { alone }\end{array}$} & \multicolumn{3}{|c|}{$\begin{array}{c}\text { MIC of antibiotic and } \\
\text { nanoparticle } \\
\mu \mathrm{g} / \mathrm{mL}\end{array}$} & \multicolumn{3}{|c|}{$\begin{array}{c}\text { MIC of } \\
\text { nanoparticle alone } \\
\mu \mathrm{g} / \mathrm{mL}\end{array}$} \\
\hline & & $\begin{array}{l}\text { Vancom } \\
\text { ycin + } \\
\mathrm{ZnO} \\
20 \mathrm{~nm}\end{array}$ & $\begin{array}{l}\text { Vancom } \\
\text { ycin + } \\
\mathrm{ZnO} \\
\text { 30nm }\end{array}$ & $\begin{array}{l}\text { Vancom } \\
\text { ycin }+ \\
\mathrm{ZnO} \\
50 \mathrm{~nm}\end{array}$ & $\begin{array}{c}\mathrm{Zn} \\
\mathrm{O} \\
20 \mathrm{n} \\
\mathrm{m}\end{array}$ & $\begin{array}{c}\mathrm{Zn} \\
\mathrm{O} \\
30 \mathrm{n} \\
\mathrm{m}\end{array}$ & $\begin{array}{c}\mathrm{Zn} \\
\mathrm{O} \\
50 \mathrm{n} \\
\mathrm{m}\end{array}$ \\
\hline 1 & 5000 & $\begin{array}{l}78.125 \\
78.125\end{array}$ & & & $\begin{array}{c}500 \\
0 \\
\end{array}$ & $\begin{array}{c}100 \\
00 \\
\end{array}$ & $\begin{array}{c}500 \\
0 \\
\end{array}$ \\
\hline 2 & 2500 & $\begin{array}{c}39 \\
78.125\end{array}$ & $\begin{array}{c}39 \\
156.25\end{array}$ & & $\begin{array}{c}500 \\
0\end{array}$ & $\begin{array}{c}100 \\
00\end{array}$ & $\begin{array}{c}100 \\
00\end{array}$ \\
\hline 3 & 5000 & $\begin{array}{l}78.125 \\
156.25\end{array}$ & & & $\begin{array}{c}100 \\
00\end{array}$ & $\begin{array}{c}100 \\
00\end{array}$ & $\begin{array}{c}500 \\
0\end{array}$ \\
\hline 4 & 2500 & $\begin{array}{c}39 \\
78.125\end{array}$ & 39 & $\begin{array}{c}39 \\
156.25\end{array}$ & $\begin{array}{c}500 \\
0\end{array}$ & $\begin{array}{c}500 \\
0\end{array}$ & $\begin{array}{c}100 \\
00\end{array}$ \\
\hline 5 & 5000 & & & & $\begin{array}{c}100 \\
00\end{array}$ & $\begin{array}{c}100 \\
00\end{array}$ & $\begin{array}{c}500 \\
0\end{array}$ \\
\hline 6 & 2500 & $\begin{array}{c}39 \\
78.125\end{array}$ & 39 & & $\begin{array}{c}500 \\
0\end{array}$ & $\begin{array}{c}100 \\
00\end{array}$ & $\begin{array}{c}100 \\
00\end{array}$ \\
\hline 7 & 50 & $\begin{array}{l}78.125 \\
156.25\end{array}$ & & $\begin{array}{r}15 \\
31 \\
\end{array}$ & $\begin{array}{c}100 \\
00 \\
\end{array}$ & $\begin{array}{c}100 \\
00 \\
\end{array}$ & $\begin{array}{c}100 \\
00 \\
\end{array}$ \\
\hline 8 & 2500 & $\begin{array}{c}39 \\
78.125 \\
\end{array}$ & $\begin{array}{c}39 \\
78.125 \\
\end{array}$ & $\begin{array}{l}78.125 \\
156.25 \\
\end{array}$ & $\begin{array}{c}500 \\
0 \\
\end{array}$ & $\begin{array}{c}500 \\
0 \\
\end{array}$ & $\begin{array}{c}500 \\
0 \\
\end{array}$ \\
\hline 9 & 5000 & $\begin{array}{c}39 \\
78.125 \\
\end{array}$ & $\begin{array}{l}78.125 \\
78.125 \\
\end{array}$ & $\begin{array}{c}156.25 \\
312.5 \\
\end{array}$ & $\begin{array}{c}100 \\
00 \\
\end{array}$ & $\begin{array}{c}500 \\
0 \\
\end{array}$ & $\begin{array}{c}100 \\
00 \\
\end{array}$ \\
\hline 10 & 2500 & $\begin{array}{c}39 \\
78.125\end{array}$ & $\begin{array}{c}39 \\
78.125\end{array}$ & $\begin{array}{c}39 \\
78.125\end{array}$ & $\begin{array}{c}500 \\
0\end{array}$ & $\begin{array}{c}500 \\
0\end{array}$ & $\begin{array}{c}500 \\
0\end{array}$ \\
\hline 11 & 2500 & $\begin{array}{c}39 \\
156.25\end{array}$ & $\begin{array}{c}39 \\
156.25\end{array}$ & $\begin{array}{c}78.125 \\
312.5\end{array}$ & $\begin{array}{c}100 \\
00\end{array}$ & $\begin{array}{c}100 \\
00\end{array}$ & $\begin{array}{c}100 \\
00\end{array}$ \\
\hline 12 & 5000 & $\begin{array}{l}78.125 \\
78.125\end{array}$ & $\begin{array}{l}78.125 \\
156.15 \\
\end{array}$ & $\begin{array}{l}78.125 \\
156.25\end{array}$ & $\begin{array}{c}500 \\
0\end{array}$ & $\begin{array}{c}100 \\
00 \\
\end{array}$ & $\begin{array}{c}100 \\
00 \\
\end{array}$ \\
\hline 13 & 5000 & $\begin{array}{l}78.125 \\
156.25\end{array}$ & $\begin{array}{l}78.125 \\
78.125\end{array}$ & $\begin{array}{l}78.125 \\
78.125\end{array}$ & $\begin{array}{c}100 \\
00\end{array}$ & $\begin{array}{c}500 \\
0\end{array}$ & $\begin{array}{c}500 \\
0\end{array}$ \\
\hline 14 & 5000 & $\begin{array}{l}78.125 \\
156.25\end{array}$ & $\begin{array}{l}78.125 \\
156.25\end{array}$ & $\begin{array}{l}78.125 \\
156.25\end{array}$ & $\begin{array}{c}100 \\
00 \\
\end{array}$ & $\begin{array}{c}100 \\
00 \\
\end{array}$ & $\begin{array}{c}100 \\
00\end{array}$ \\
\hline
\end{tabular}

\section{DISCUSSION}

\section{A. Antibiotic Sensitivity Test}

Vancomycin and Oxacillin which is one of the methicillin group, as it resisted 13 isolates with a resistance rate of $92.8 \%$, which corresponds to many studies with a percentage of 93.42\%, 93.53\%, 95\% (Salih et al., 2017; Kandala; et al. 2017; Mohammed and Flayyih, 2017), respectively. the sensitivity of S. aureus for methicillin MSSA, at a rate of $7.1 \%$, and this result is consistent with the study Al-Maliki (2009), which was sensitive to methicillin 3.3\%.

Also, the results of our study were in agreement with the study of Al-Geobory (2011), which showed the percentage of resistance to methicillin up to $90.9 \%$, as well as the study of AlDahbi and Al-Mathkhury (2013) showed the percentage of resistance to methicillin up to $94.3 \%$. While it did not agree with the study of Peck et al. (2009), which showed the percentage of methicillin resistance to $51.4 \%$ and methicillin sensitive $48.6 \%$.

The MRSA strains contain the $S c c$ mec gene integrate within the scc mec chromosomal orf $x$ gene, which are motile genetic elements that vary in size and genetic arrangement between the various MRSA strains that contain the mecA or mecC methicillin resistance gene, which encodes PBP2a enzymes that have little or low affinity for each of the group of $\beta$-lactams, except for the fifth generation of cephalosporins such as Ceftaloridin and Ceftobiprole, or possibly S. aureus produces a PVL toxin that is a two-component capable of inducing holes that destroy leukocytes (Meyer et al., 2009) and stimulating the expression of other harmful agents (McDonald et al., 2005).

The mechanism of resistance may occur due to a mutation in the mecA gene in an increase or decrease that produces antimicrobial resistance in addition to other antibiotic resistance genes present in the cassette, leading to multiple drug resistance (Duran et al., 2012).

Antibiotics are related to proteins responsible for the strength and durability of the cell wall and are called penicillin binding proteins PBPs. The cause of resistance may also be the presence of the mecA gene, which reduces the antibiotic's binding to proteins responsible for cell wall strength and called penicillin binding proteins (Ekrami et al., 2010).

The results of this study are in agreement with the study of Talebi et al. (2019) where the percentage of resistance to Oxacillin were 90\%. Beta-lactam antibiotics inhibit the processes of manufacturing the cell wall by interfering with the process of manufacturing the peptidoclycan layer. The cause of resistance may be due to the secretion of beta-lactamase enzymes, which may be plasmid or chromosomal, or due to the secretion of bacteriostatic inhibitory enzymes, which may also be plasmid or chromosomal, which are used to neutralize the effects of beta-lactam antibiotics by breaking the beta-lactam cycle in the penicillins and cephalosporins group (Kolár et al., 2010).

13 S. aureus show resistant to Vancomycin (VRSA) at a rate of $92.8 \%$, and this percentage is somewhat consistent with the study conducted by the researcher Al-Khafaji in (2018), as the resistance rate was $100 \%$.

Decreased sensitivity strains of $S$. aureus of vancomycin may led or may be associated with alteration of the bacterial target, including an increase in the thickness of the bacterial cell wall that blocks or retains Vancomycin and prevents it from reaching the target (Gonzalez-Zoom, 2003). However, a decrease in the cross-linkages of the peptidoclycan layer and a higher content of free D-alanin-D-alanin in the cell wall may increase the resistance of the strain. 
Vancomycin resistance is a result of either the transmission of genes encoding resistance to the VanA gene carried on conjugated plasmids or transposon genes from other strains and S. aureus (Reipert et al., 2003).

The cell wall plays an important role in increasing the resistance of bacteria to antibiotics, by increasing the manufacture of amino acids required to build the cell wall such as Alanin and sugars such as $\mathrm{N}$-acetyl glucosamine, which helps the cell to build a thick cell wall to show the highest level of resistance (Kuroda et al., 2000).

\section{B. Measurement of the minimum inhibitory concentration of vancomycin and zinc nanoparticles}

MIC results of the current study contradicted the results of several studies, including the study of the researcher Karim (2015), where the MIC values were (2500-325) $\mu \mathrm{g} / \mathrm{mL}$ for $\mathrm{ZnO}$ 20 and $\mathrm{ZnO} 150-50$ and $\mathrm{nm} 30$ and the MIC values were between (2600-126.5) $\mu \mathrm{g} / \mathrm{mL}$ Whereas in Abdulrahman and Nssaif (2016) the MIC values for $\mathrm{ZnO} 20$ were (256) $\mu \mathrm{g} / \mathrm{mL}$, the MIC for $\mathrm{ZnO} 30$ was (341) $\mu \mathrm{g} / \mathrm{mL}$ and $\mathrm{ZnO} 150-50$ was (160) $\mu \mathrm{g} / \mathrm{mL}$.

MIC results in the study of Nazoori and Kariminik (2018) were $\mathrm{ZnO}(2500-5000) \mu \mathrm{g} / \mathrm{mL}$ but for other bacterial species.

In the study of Aleaghil et al. (2016), the MIC values of $\mathrm{ZnO}$ ranged between (5000-625) $\mu \mathrm{g} / \mathrm{mL}$, which was close to the results of the current study.

The difference in MIC between the isolates is due to the size and concentration of the nanoparticles (Yamamoto et al., 2001) as well as the smaller nanoparticles will increase the surface area and thus the active groups will increase and the toxicity result of the nanoparticles increases (Aleaghil et al., 2016).

The high resistance to MRSA and VRSA in the current study was also proven by the study of Ansari et al. (2012). They found that the MIC of $\mathrm{ZnO}$ to MRSA could reach to $2000 \mu \mathrm{g} / \mathrm{mL}$.

Several mechanisms have been proposed to explain the effectiveness of $\mathrm{ZnO}$, including the production of hydrogen peroxide, which is an important factor in inhibiting bacterial growth (Yamamoto, 2001). Another mechanism is the release of zinc ions that work with $\mathrm{H}_{2} \mathrm{O}_{2}$ to break down or disrupt cell membrane lipids and proteins and thus lead to leakage of internal cellular contents. For cells and ultimately cell death, which is caused by the small size of the cell with an increase in surface area, which leads to an increase in the effectiveness of $\mathrm{ZnO}$ (Xie et al., 2011). Zinc oxide can interfere with Nor A protein, which is an advanced protein to confer resistance in bacteria and has pumping efficacy that leads to pumping Or the escape of hydrophilic fluoroquinolones from the cell, another illustration is that $\mathrm{ZnO}$ can interfere with the Omf protein, which is a membrane protein responsible for the permeability of quinolones into the cell (Banoee et al., 2010).

The mechanism by which nanoparticles interact in general with bacterial cells is that microorganisms carry a negative charge while metal oxides carry a positive charge, which creates an electromagnetic attraction between the bacteria and the surface of the minute and that the nanoparticles release ions that interact with the thiol group (-SH) Of nutrient transport proteins that emerge from the bacterial cell membrane, which reduces membrane permeability and thus cell death (Zhang and Chen, 2009).

\section{V.CONCLUSION}

The highest percentage of bacterial isolation from wounds. Vancomycin gave an synergistic effect with zinc oxide nanoparticle in the three sizes, but the highest effect with $20 \mathrm{~nm}$ zinc oxide nanoparticle.

\section{CONFLICT OF INTEREST}

The authors declare no conflict of interest

\section{REFERENCES}

Abdulrahman, N.B., Nssaif, Z.M. (2016). Antimicrobial Activity of Zinc Oxide, titanium Dioxide and Silver Nanoparticles Against MithicillinResistant Staphylococcus aureus Isolates. Tikrit Journal of Pure Science, 21, 3, 49-53.

Ahmadi Shadmehri, A., Namvar, F., Miri, H., Yaghmaei, P., Nakhaei Moghaddam, M. (2019). Assessment of antioxidant and antibacterial activities of Zinc Oxide nanoparticles, Graphene and Graphene decorated by Zinc Oxide nanoparticles . International Journal of Nano Dimension, 10: 350-358.

Al-Dahbi, AM. And Al-Mathkhury, H.J. (2013). Distribution of Methicillin Resistant Staphylococcus aureus in Iraqi patients and Healthcare Workers. Iraqi Journal of Science, 54 (2), 293-300.

Aleaghil, S.A., Fattahy, E., Baei, B., Saghali, M., Bagheri, H., Javid, N., Ghaemi, E.A. (2016). Antibacterial activity of Zinc oxide nanoparticles on Staphylococcus aureus. International Journal of Advanced Biotechnology and Research , 7, 569-1575.

Al-Geobory, H.A.H. (2011). Comparative Study between Methicillin Resistant Staphylococcus aureus (MRSA) and Methicillin Sensitive Staphylococcus aureus (MSSA), and detect the Antimicrobial Effects of some Plant Extracts on them. Msc. Thesis. College of Science/ Baghdad University. Iraq.

Al-Khafaji, A.N. (2018). Isolation and Identification of Methicillin Resistance Staphylococcus aureus and Detection their Ability to the Production of Virulence Factors. Journal of University of Babylon for Pure and Applied Sciences, 26(8)

Al-Maliki, A.A.A. (2009). A study of some Methicillin-Resistant Staphylococcus aureus (MRSA) and (MRSE) Isolated from Baghdad Hospital Patients. M.Sc. Thesis. College of Science. AL-Mustansiriya University.

Ansari, M.A., Khan, H.M., Khan, A.A., Sultan, A., Azam, A. (2012). Characterization of clinical strains of MSSA,MRSA and MRSE isolated from skin and soft tissue infestions and the antibacterial activity of $\mathrm{ZnO}$ nanoparticles. World Journal of Microbiology and Biotechnology, 28(4), 1605-1613.

Asanin, J., Misic, D., Aksentijevic, K., Tambur, Z., Rakonjac, B., Kovacevic, I., Spergser, J., Loncaric, I. (2019). Genetic Profiling and Comparison of Human and Animal Methicillin-Resistant Staphylococcus aureus (MRSA) Isolates from Serbia. Antibiotics, 8, 26. doi:10.3390/antibiotics 8010026

Banoee, M., Seif, S., Nazari, Z.E., Jafari-Fesharaki, P., Shahverdi, H.R., Moballegh, A., Moghaddam, K.M., Shahverdi, A.R. (2010). ZnO Nanoparticles enhanced antibacterial activity of ciprofloxacin against Staphylococcus aureus and Escherichia coli. Journal of Biomedical Materials Research, 93, 557-561. 
Bauer, A.W., Kirby, M.M., Sherris, J.C., Turck, M. (1966). Antibiotic susceptibility testing by standardized single disc method. American Journal of Clinical Pathology, 45(4), 493-496.

Cho,WS., Duffin, R., Howie, SE., Scotton, CJ., Wallace, WA., Macnee, W., Bradley, M., Megson, IL., Donaldson, K. (2011). Progressive severe lung injury by zinc oxide nanoparticles, the role of $\mathrm{Zn} 2+$ dissolution inside lysosomes. Part Fibre Toxicol 8:27.

Clinical and Laboratory Standards Institute, CLSI (2019). Performance Standards for Antimicrobial Susceptibility Testing. $29^{\text {th }}$ ed. CLSI supplement M100., 39(1), 42-45,58-67

Collee, J.G., Fraser, A.G., Marmion, B.P., Simmon, S.A. (1996). Mackie and McCartney Practical Medical Microbiology. (14 ${ }^{\text {th }}$ Ed.) Churchill Livingston, U.S.A.

Duran, N., Ozer, B., Duran G. G., Onlen, Y., Demir, C. (2012). "Antibiotic resistance genes \& susceptibility patterns in Staphylococci," Indian Journal of Medical Research,135(3), 389-396.

Ekrami, A., Samarbafzadeh, A.R., Alavi, M., Kalantar, E., Hamzeloi, F. (2010). Prevalence of methicillin resistant Staphylococcus sp. isolated from burn patients in a burn center, Ahvaz, Iran. Jundishapur Journal of Microbiology, 3,84-91.

Fayaz, A.M., Balaji, K., Girilal, M., Yadav, R., Kalaichelvan, P.T., Venketesan, R. (2010). Biogenic synthesis of silver nanoparticles and their synergistic effect with antibiotics: a study against gram-positive and gram-negative bacteria. Nanomedicine, 6(1),103-9. doi: 10.1016/j.nano.2009.04.006.

Gonzalez-Zom, B., Courvalin, P. (2003). "Van Amediated high level". Glycopeptide resistance in MRSA. The Lancet Infectious Diseases, 3, 6768.

Goudarzi, G., Tahmasbi, F., Anbari, K., Ghafarzadeh, M. (2016). Distribution of genes encoding resistance to macrolides among staphylococci isolated from the nasal cavity of hospital employees in Khorramabad, Iran. Iranian Red Crescent Medical Journal, 18, 25701.

Hajipour, M.J., Fromm, K.M., Ashkarran, A.A., Aberasturi, D.J., Larramendi, I.R., Rojo,T., Serpooshan,V., Parak, W.J., Mahmoudi, M. (2012). Antibacterial properties of nanoparticles. Trends in Biotechnology, 30(10),499-511.

Kandala, N.J., Abdulateef, A., Imad, N. (2017). Genotyping of Staphylococcus aureus Isolated Based on Methicillin -Resistant Genes and its Relatedness to some Putative Virulence Factors.Iraqi Journal of Science,58(2A), 626-638.

Kolář, M., Bardoň, J., Hanulík, V., Sauer, P., Babák, V., and Schlegelová, J. (2010). "Resistance to methicillin in coagulase-negative Staphylococci and Its Detection". Acta Veterinaria Brno,79,261-267.

Kołodziejczak-Radzimska, A., Jesionowski, T. (2014). Zinc oxide - from synthesis to application: a review. Materials,7,2833-2881.

Kuroda, M., Kuwahara-Arai, K., Hiramatsu, K. (2000). "Identification of the up and down-regulated genes in vancomycin-resistant Staphylococcus aureus strains Mu3 and Mu50 by cDNA differential hybridization method".Biochemical and Biophysical Research Communications, 269, 485-490.

Maruthupandy, M., Anand, M., Maduraiveeran, G., Suresh, S., Beevi1, A.S., Priya1, R.J. (2016). Investigation on the electrical conductivity of $\mathrm{ZnO}$ nanoparticles-decorated bacterial nanowires. Advances in Natural Sciences, 7(9),045011.

McDonald, R.R., Antonishyn, N.A., Hansen, T., Snook, L.A., Nagle, E., Mulvey, M.R., Levett, P.N., Horsman, G.B. (2005). Development of a triplex real-time PCR assay for detection of Panton-Valentine leukocidin toxin genes in clinical isolates of methicillin-resistant Staphylococcus aureus. Journal of Clinical Microbiology,43(12), $6147-$ 6149.doi:10.1128/JCM 43 .12.6147-6149.

Meyer, F., Girardot, R., Piemont, Y., Prévost, G., Colin, D.A. (2009). Analysis of the specificity of Panton-Valentine leucocidin and gamma-hemolysin F component binding. Infection and Immunity,77(1), 266-273.

Mohammed, L.S., Flayyih, M.T. (2017). Patterns of Phenotypic and Genotypic Resistance to Macrolides, Lincosamides and Streptogramins Group of Antibiotics by Efflux Pump and Enzymatic Modification in Methicillin Resistant Staphylococcus aureus .Iraqi Journal of Science,58(2B):815819.

Nazoori, E.S., Kariminik, A. (2018). In vitro Evaluation of Antibacterial Properties of Zinc Oxide Nanoparticles on Pathogenic Prokaryotes. Journal of Applied Biotechnology Reports,5(4),162-165.
Pati, R., Mehta, R.K., Mohanty, S., Padhi, A., Sengupta, M., Vaseeharan, B., Goswami, C., Sonawane, A. (2014). Topical application of zinc oxide nanoparticles reduces bacterial skin infection in mice and exhibits antibacterial activity by inducing oxidative stress response and cell membrane disintegration in macrophages. Nanomedicine, 10,1195-1208.

Peck, K.R., Baek, J.Y., Song, J-H., Ko, K.S. (2009).“Comparison of genotypes and enterotoxin genes between Staphylococcus aureus isolates from blood and nasal colonizers in Korean hospitals". Journal of Korean Medical Science, 24,585-591.

Rao, K.A., Deepa, S., Venkatsha, D. (2014). Screening for nasal colonizer: Mandatory to prevent surgical site infections. International Journal of Scientific Study,2(5),1-5.

Reddy, P.N., Srirama, K., Dirisala, V.R. (2017). An Update on Clinical Burden, Diagnostic Tools, and Therapeutic Options of Staphylococcus aureus. Infectious Diseases: Research and Treatment, 10,1-15.

Reipert, A., Ehlert, K., Kast, T., Bierbaum, G. (2003). Morphological and genetic differences in two isogenic Staphylococcus aureus strains with decreased susceptibilities to vancomycin. Antimicrobial Agents and Chemotherapy, 47(2), 568-576.

Saginur, R., Denis, M.S., Ferris, W., Aron, S.D., Chan, F., Lee, C., Ramotar, K. (2006). Multiple Combination bactericidal testing of Staphylococcal biofilms from implant-associated infections. Antimicrobial Agents and Chemotherapy,50(1),55-61.

Salih, R.M.H., Rafiq, S.N., Hamed, P.A. (2017). Vancomycin Resistance among Methicillin Resistant Staphylococcus aureus isolated from Clinical Samples in Erbil City, Iraq. Kirkuk University Journal $\backslash$ Scientific Studies (KUJSS), 12(2),1-14.

Siddiqi, K.S., Rahman, A., Tajuddin, Husen, A. (2018). Properties of Zinc Oxide Nanoparticles and Their Activity Against Microbes. Nanoscale Research Letters, 13,141.

Slomberg, D.L., Lu, Y., Broadnax, A.D., Hunter, R.A., Carpenter, A.W., Schoenfisch, M.H. (2013). Role of size and shape on biofilm eradication for nitric oxide-releasing silica nanoparticles. ACS Applied Materials \& Interface.,5(19), 9322-9329.

Talebi, G., Hashemia, A., Goudarzi, H., Shariati, A., Bostanghadiri, N., Sharahi, J.Y., Abbsi, E. (2019). Survey of ermA, ermB, ermC and mecA genes among Staphylococcus aureus isolates isolated from patients admitted to hospitals in Tehran, Iran by PCR and sequencing. Biomedical Research, 30

Tille, P.M. (2017). Baily and Scott's Diagnostic Microbiology. $14^{\text {th }}$ ed. St.Louis, Missouri: Elsevier.

Tong, SY., Davis,JS., Eichenberger,E., Holland, TL., Fowler, VG.(2015). Staphylococcus aureus infections: Epidemiology, path physiology, clinical manifestations and management. Clinical Microbiology Reviews, 28(3), 603-661.

Tortora, G.J., Funke, R., Case, C.L. (2018). Microbiology: an introduction. $13^{\text {th }}$ ed. Pearson Education, Inc. U. S

Wang, C., Lu, J., Zhou, L., Li, J., Xu, J., Li, W., Zhang, L., Zhong, X., Wang, T. (2016). Effects of long-term exposure to zinc oxide nanoparticles on development,zinc metabolism and biodistribution of minerals $(\mathrm{Zn}, \mathrm{Fe}, \mathrm{Cu}$, $\mathrm{Mn}$ ) in mice.PLoS One., 11,e0164434.

Winn, W., Allen, S., Janda, W., Koneman, E., Procop, G., Schreckenberger, P., Woods, G. (2006). Koneman's Color Atlas and Textbook of Diagnostic Microbiology. 6th Ed., Lippincott, Williams\&Wilkins.

Xie, Y., He, Y., Irwin, P.L., Jin, T., Shi, X. (2011). Antibacterial activity and mechanism of action of zinc oxide nanoparticles against Campylobacter jejuni.Applied and EnvironmentalMicrobiology,77(7), 2325-2331.

Yamamoto, O. (2001)."Influence of particle size on the antibacterial activity of Zinc oxide". International Journal of Inorganic Materials, 3(7), 643-646.

Yamamoto, O., Komatsu, M., Sawai, J., Nakagawa, ZE. (2004). Effect of lattice constant of zinc oxide on antibacterial characteristics .Journal of Materials Science: Materials in Medicine, 15, 847-851

Zhang, H. and Chen, G. (2009). Potent Antibacterial Activities of Ag/TiO 2 Nan composite Powders Synthesized by a One-Pot Sol-Gel Method.Environmental Science \& Technology, 43(8), 2905-2910.

Zhang, L., Jiang, Y., Ding, Y., Povey, M., York, D. (2007). Investigation into the antibacterial behaviour of suspensions of $\mathrm{ZnO}$ nanoparticles $(\mathrm{ZnO}$ nanofluids). Journal of Nanoparticle Research ,9(3), 479-489. 